Document downloaded from:

http://hdl.handle.net/10251/154116

This paper must be cited as:

Montero De Vicente, L.; Roig-Merino, B.; Buitrago Vera, JM.; Sigalat-Signes, E. (2019).

Characterisation of fresh fruit consumption in Spain based on food-related lifestyle. British Food Journal. 121(12):3307-3320. https://doi.org/10.1108/BFJ-04-2019-0253

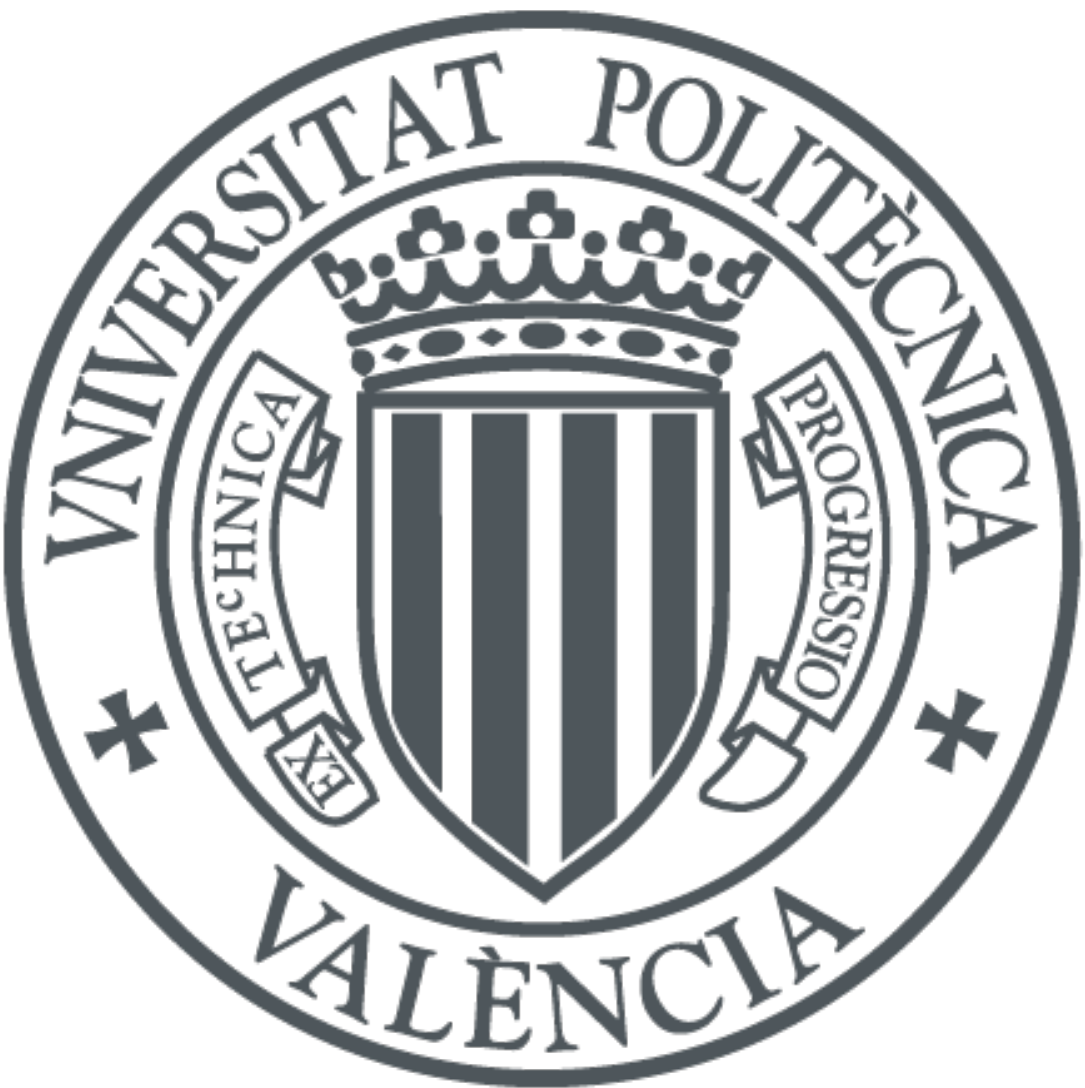

The final publication is available at

https://doi.org/10.1108/BFJ-04-2019-0253

Copyright Emerald

Additional Information 


\section{CHARACTERISATION OF FRESH FRUIT CONSUMPTION IN SPAIN BASED ON FOOD-RELATED LIFESTYLE ${ }^{1}$}

\begin{tabular}{|r|l|}
\hline Journal: & British Food Journal. Vol. 212 No 12 \\
\hline DOI & $10.1108 /$ BFJ-04-2019-0253 \\
\hline Manuscript Type: & Research Paper \\
\hline Keywords: & Spain, Market segmentation, Fruit, Lifestyles, Personal values, Food \\
\hline
\end{tabular}

$\left.{ }^{*}\right)$ Luis Montero-Vicente luimonvi@esp.upv.es

$\left({ }^{*}\right)$ Bernat Roig-Merino bernat@upv.es

(*) Juan Buitrago-Vera, jmbuitrago@esp.upv.es

$\left.{ }^{* *}\right)$ Enrique Sigalat-Signes enrique.sigalat@uv.es

(*) Department of Economics and Social Sciences, Universitat Politècnica de València, Valencia, Spain.

$\left.{ }^{(* *}\right)$ Department of Social Work and Social Services, Universitat de València, Valencia, Spain.

\section{Acknowledgements}

The authors thank the Consum Business Chair of the Universitat Politécnica de València, for its support in this research.

\section{ABSTRACT}

The purpose of this paper is to describe fresh fruit consumers in Spain according to their foodrelated lifestyle (FRL).

A random stratified sample of 500 people, representative of the persons responsible for household food purchasing and resident in Spain, was interviewed in 2017 using a revised and adapted version of the FRL instrument (Grunert et al., 1993). Questions about fruit purchasing criteria, consumption habits and demographics were also included. Factor and cluster analysis (Ward Method) yielded four segments.

The segments identified are: (i) "Total indifference (TI)", small segment with disinterest in extradomestic and social consumption, nutrition and innovation; (ii) "Little time to cook, concerned about nutrition and extra-domestic consumption (LICNE)", the largest consumers of fresh fruit who show interest in nutrition and health, but no interest in the price of products, convenience foods or liking cooking (iii); "Cooks and preference for natural products (COOKNAT)", the largest segment, with a medium-high consumption of fresh fruits, who are related to cooking at home, natural products and a concern for the price-quality ratio; (iv) "Unconcerned (UNC)" presents the lowest fresh fruit consumption and shows the lowest interest in natural products and some indifference to the other criteria.

The information obtained in this study gives interesting new insights for the marketing strategies of the fresh fruit suppliers to Spain and the Food and Public Health Administrations.

\footnotetext{
${ }^{1}$ This Author Accepted Manuscript is deposited under the Creative Commons Attribution Noncommercial International Licence 4.0 (CC BY-NC 4.0) and any reuse is allowed in accordance with the terms outlined by the licence. To reuse the AAM for commercial purposes, permission should be sought by contacting permissions@emeraldinsight.com
} 


\section{INTRODUCTION}

Fruits, along with vegetables and other basic foodstuffs, are essential components of a healthy diet. Low fruit consumption is associated with poor health and the risk of non-communicable diseases (WHO, 2003) such as coronary disease, diabetes or obesity, which have become a public health problem in developed countries. In Spain, the so-called Mediterranean diet predominates, with one of the highest consumption levels of fruits and vegetables in Europe (EUROSTAT, 2016). However, obesity is rapidly catching up in Spain, as in the rest of Europe (OECD, 2017), and the Spanish population does not reach the recommendations stipulated by the scientific and health community to consume a minimum of five pieces of fruit and vegetables per day (Arroyo et al., 2018).

According to Cooremans et al. (2017), several researchers assume that consumers' attitudes towards food (e.g., the liking for fast food) and the importance given to different food characteristics (e.g., health and taste) have largely contributed to the worldwide prevalence of obesity.

There are different techniques to segment consumers and explain their attitudes and behaviour towards different products. Traditionally, socioeconomic and demographic features have been used, providing interesting results (Kavak and Gumusluoglu, 2007). However, today's food consumption is too complex to be explained by socio-demographic factors exclusively (Verain et al., 2012). The use of psychographic variables, values and lifestyles can solve this problem and is very relevant when pinpointing consumer segments (Fraj Andrés et al., 2004), attempting to group consumers according to their lifestyles and values (Law, 2016; Kotler et al., 2014), currently becoming a dimension of great importance for market segmentation. Limeira (2008) states that lifestyle is understood as the consumption pattern of an individual, reflecting their personal values and tastes.

With the explicit aim of its use as a tool in international segmentation in the food domain, in 1997 Bruns $\varnothing$ developed the FRL construct (Grunert, 2019). This instrument groups consumers based on their attitudes towards the purchase, preparation and consumption of food products, and includes a number of quality aspects such as health, freshness and taste (Buckley et al., 2005). Pérez-Cueto et al. (2010) related obesity to some domains of FRL in five European countries and Dimech et al. (2011) examined the influence that Maltese consumers' lifestyles have on their attitudes towards quality features of fruit and vegetables.

The FRL instrument has been validated by relating it to various aspects of self-reported foodrelated behaviour with good results, and has been used in more than a hundred studies in different countries (Grunert, 2019). This instrument seems to work well in Western cultures, but attempts to apply it in other parts of the world have been less successful (Grunert et al., 2011). The FRL instrument links personal values with behaviours and posits five domains: (i) Purchasing behaviour (Ways of Shopping), (ii) Food preparation methods (Cooking Methods), (iii) Qualitative aspects (Quality Aspects), (iv) Consumer situations (Consumption situation) and (v) Food choice motivation (Purchasing Motives). The full FRL questionnaire has 69 items that measure 23 dimensions, on a 7 point Likert scale (1, "Strongly disagree" to 7 "Strongly agree") (Scholderer et al., 2004). It can include different numbers of items in order to adapt to the study characteristics as other authors have done.

In Spain, the FRL has been used for segmenting consumers of different types of meat (Bernués et al., 2012; Buitrago-Vera et al., 2016; Escriba-Perez et al., 2017) at a national or regional level. But there are no previous studies in Spain relating fresh food consumption with FRL. Out of Spain, some studies have related FRL with the consumption of specific food products (e.g., speciality foods in Wycherley et al., 2008; convenience foods in Buckley et al., 2005 and Ryan et al., 2004; organic and local food in Nie and Zepeda, 2011 and Van Huy et al., 2019) but only the above cited of Dimech et al. (2011) was related in some way to fresh fruit purchasing and consumption. 
The aim of this study is to segment Spanish food shoppers using a revised and previously tested version of the FRL instrument to better determine the size and profile of the Spanish FRL segments, and their relationship with fresh fruit purchasing and consumption criteria.

\section{MATERIAL AND METHODS}

\section{Study area and sample selection}

For the sample selection, the respondent should be the person responsible for food purchasing in the household, between 25 and 74 years of age and resident in Spain. The sampling process was probabilistic, stratified by proportional geographic allocation, within the scope of peninsular Spain divided into Nielsen areas (North East, East, South, Central, North West, North-Central, Madrid and Barcelona), to reflect the distribution of population in Spain according to official statistics (Table 1).

The valid sample size was 500 subjects, which gave a sampling error of $4.47 \%$ for percentages, with a confidence level of $95.5 \%$ and $p=q=50 \%$. This sampling error was lower than the maximum limit of $5 \%$ established in social sciences (Morales, 2008). Table 1 shows that the sample represented the Spanish population in 2017 quite well in terms of age of respondents, number of people in the household and geographic area. In $95 \%$ of the categories in Table 1, the sample bias was less than the sampling error for that confidence level.

Table 1

\section{Data collection and variables}

The fieldwork was carried out by a specialist company in the second half of June 2017, through telephone interviews lasting approximately 12 minutes, using Computer Assisted Telephone Interview (CATI) software and selecting the interviewees randomly from public telephone directories. Individuals not responsible for food purchasing in the household, not between 25 and 74 years old or not resident in Spain were ruled out.

The questionnaire consisted of 39 questions divided into 7 blocks to assess consumer experience with fresh fruit globally. This way, block 1 was intended as a filter when choosing the consumer. Blocks 2 and 3 were designed to gather information on consumer purchasing habits and frequency. Block 4 and 5 attempted a more in-depth examination of the purchasing and consumption criteria. Block 6 was included to characterise the consumer's FRL, using the FRL instrument (Grunert et al., 1993). Finally, block 7 was intended for the socioeconomic and demographic identification of the respondent and the household.

As stated in the Introduction, the FRL model may comprise a different number of items in order to adapt to each context. In this study, block 6 had 16 items measured on a 5-point Likert scale ranging from 'strongly disagree' (1) to 'strongly agree' (5), with a middle point of 'neither agree nor disagree' (3). This 16 items scale had been previously tested in Montero-Vicente (2015) and Escriba-Perez et al. (2017). The two criteria for selection of the 16 items from the original 69 items of the FRL instrument developed by Bruns $\varnothing$ in 1997, were: not to fatigue the interviewee by asking too many questions, and to maintain at least one item for each of the five domains of the construct.

\section{Statistical analysis}

The statistical data analysis techniques used in this study were univariate analysis, bivariate analysis and multivariate analysis, using IBM SPSS Statistics 20 (SPSS, 2011). Basic statistics and frequency distributions were used to perform an exploratory and descriptive processing of the 
results obtained. Using the frequency tables, outliers that could bias later analyses could be more easily identified (Pérez-López, 2004). The bivariate analysis was performed through cross tabulations and the Pearson correlation coefficient to measure the degree of association between variables.

The multivariate analysis was used for reduction of the FRL-related items, obtaining five factors and ensuring minimal information losses through the Bartlett sphericity test and the KaiserMeyer-Olkin sample adequacy measure (KMO).

Finally, the cluster analysis was configured by hierarchical procedure. Ward's method was applied to obtain the clusters, using squared Euclidean distance as a measure of similarity between objects. To decide the optimal number of clusters, a dendrogram was used (Uriel and Aldás, 2005), which allows a visual representation of a hierarchical segment and shows the different clusters formed. For segmentation purposes, it is generally believed that Ward's method gives the most consistent performance (France and Ghose, 2019). Examples of this methodology can be found in Escriba-Perez et al. (2017), Montero-Vicente (2015), Bernués et al. (2012) and Dimech et al. (2011). Once the cluster solution was obtained, its quality was measured by analysis of variance (Hair et al., 2008).

The most detailed features of each of the segments would be obtained by crossing the factorial scores with the rest of variables of the questionnaire, describing the fruit consumption criteria, purchasing habits and demographic characteristics of the respondents.

\section{RESULTS AND DISCUSSION}

\section{Descriptive statistics}

Table 2 shows the descriptive statistics of the items in the block 6 .

\section{Table 2}

Items with a higher percentage of responses in the "Strongly agree" option are coherent with what was expressed by Díaz (2014) when stating that Spaniards consider mealtimes as a social event. The preference for fresh and natural products (fresh/without preservatives) and the search for an intelligent and efficient purchase (trade-off between price and quality) also stands out, in the same way as Pasamón (2010) states.

The item "I often decide what to cook at the last minute" has the lowest percentage in the "Strongly agree" option. This result validates the findings of some authors who state that the Spanish consumer uses ready-to-eat foods moderately, compared to the other European countries (Resa, 2007). This low value thus reinforces the previous point regarding the shift towards intelligent and efficient purchasing.

\section{Analysis and reduction of the number of items according to FRL}

The factors were extracted using the principal component analysis (PCA), considering eigenvalues greater than 1 . Previously, a reliability analysis was carried out to determine the degree of internal consistency of the FRL scale used by the application of Cronbach's Alpha, whose result improved if item 13: "I often decide what to cook at the last minute" was eliminated.

The Bartlett sphericity test, with a p-value of 0.000 at a significance level of 0.05 , demonstrated that the factorial analysis was adequate (Uriel and Aldás, 2005). In addition, the KMO measure showed a value of 0.719 , which was valid, as the minimum acceptable is 0.5 (Hair et al., 2008). 
The PCA yielded five factors (Table 3 ) that explained $53.9 \%$ of the total variance. This result was accepted because, in the social sciences, a value of $60 \%$-or even less- at the level of explanation of variance is considered acceptable (Hair et al., 2008).

Table 3

After applying a varimax rotation, table 4 shows the factor loadings of each variable on the five factors:

Table 4.

According to Hair et al. (2008), for a sample size of 350 cases or higher, a factor load value greater than 0.3 is considered significant. Thus, analysing factor loading of each variable, the five identified factors are defined as follows: (i) Overall liking of cooking, (ii) Interest in natural products; (iii) Quality-price ratio, involved and convenience; (iv) Extra-domestic and social consumption; (v) Little time to cook, but interested in nutrition and innovation.

\section{Obtaining and naming the market segments}

To obtain the FRL segments, a cluster analysis was performed using hierarchical procedures. The Euclidean squared distance was used as a measure of similarity between objects, and Ward's method as a form of aggregation to yield the clusters. This gave rise to a dendrogram indicating that the ideal number of clusters was four. Finally, to validate the results, two tests were performed. Firstly, the ANOVA showed that the means of the factors were significantly different among the segments. Secondly, the Brown-Forsythe, for a significance level $<0,01$, also demonstrated that the segments were different. This way, four segments were obtained, whose factor loadings are shown in Table 5. These factor loadings are used to name and each segment in the next paragraph.

Table 5.

(i) Total indifference ( $\mathrm{TI}$ ) is the smallest ( $4 \%$ of the sample). It is characterised by all factorial loads being negative, which means that they behave in a manner contrary to the assertion of each factor. The respondents' scant interest in extra-domestic and social consumption is notable, along with disinterest in nutrition and innovation or, to a lesser extent, in natural products. The factor related with value for money of products and convenience is close to 0 , so we can affirm that there is a degree of indifference towards it. (ii) Little time to cook, concerned about nutrition and extra-domestic consumption (LICNE) represent $26.4 \%$ of the sample. Positive factorial loads are shown both in factor 5 and factor 2, both strongly linked with nutrition and health. The respondents show no interest in the price of products, convenience foods or liking cooking, not due to lack of interest but because they have no time for cooking, as indicated by the high score of factor 5 . (iii) Cooks and preference for natural products (COOKNAT) represents $40.2 \%$ of the sample. They have an affinity for cooking and a preference for natural products, as well as a concern for the price-quality ratio of food. They show no interest in nutrition and innovation, which relates them to more traditional cooking practices. The negative load in extra-domestic consumption represents a degree of preference for cooking at home. (iv) Unconcerned (UNC) accounts for $29.4 \%$ of the sample. It has a certain similarity with segment 1 "Total indifference", but in contrast some of the scores of its factorial loads are slightly positive, highlighting a certain interest in cooking and concern for nutrition. However, as these are the lowest scorers compared to the rest of the segments and being so close to 0 , it could be considered as some degree of indifference. Interest in natural products received the highest negative score in this segment. 


\section{Description and characterisation of the segments}

The consumer profile of each of the four segments obtained was developed using bivariate analyses, specifically cross tabulations and correlation tests (Sánchez el al., 2002), with a significance level of $1 \%, 5 \%$ and $10 \%$.

The variables that were not significant (significance level above 10\%), and which will therefore not be used to describe the behaviour of the segments, are as follows:

- Fresh fruit purchasing frequency (Block 2).

- Purchase location (Block 2).

- Importance given to recommendation from a doctor or nutrition specialist (Block 5).

- Presence or not of children under 18 (Block 7).

- Geographical area of residence (Block 7).

- Residence in a metropolitan area or not (Block 7).

- Sex of the interviewee (Block 7).

Tables 6 - 9 describe the consumer profile of the four FRL segments, showing in bold the segment values that exceed the total average by more than four percentage points.

Table 6

Table 7

Table 8.

Table 9

According to these tables, the segment profiles (sociodemographic and related to fresh fruit purchasing and consumption) are:

\section{Segment 1}

Total Indifference (TI): People aged 65 to 74 years (45\%), households composed of 1 to 2 members (50\%) and the residential habitats of 100,001 to 500,000 inhabitants (30\%) stand out above the total average. Although these respondents have little interest in food, they consume fruit daily, with values similar to those of the total sample. In contrast, and with respect to the rest of the segments, they give little importance to all the fresh fruit purchasing and consumption criteria.

\section{Segment 2}

Little time to cook, concerned about nutrition and extra-domestic consumption (LICNE): This segment is characterised by a greater proportion of individuals between 45 and 54 years old $(30.3 \%)$, and the few people aged from 25 to 34 years (6.8\%). In this segment, households consisting of 1 to 2 people (40.9\%) stand out over the average. Respondents in this segment are distinguished by consuming fruit three times a day or more $151.5 \%$ of the segment, being the highest value). This value is consistent with the concern for nutrition found in this segment, in addition to the little time available for cooking, which could indicate that they resort to fresh foods that do not require any preparation. As for the purchasing criteria, this segment along with the COOKNAT stand out for giving greater importance to all the criteria (geographical origin, product appearance, advice from the fruiterer, product information and brand) excepted the 
product price, in which the LICNE segment does not differ from the total average. Finally, they give greater importance than the total average to the fresh fruit consumption criteria (healthy, flavour and non-fattening), but less than the COOKNAT segment (as occurs with the fruit price criteria).

\section{Segment 3}

Cooks and preference for natural products (COOKNAT): Four-person households stand out $(34.8 \%)$ and the residential habitat in localities of 50,001 to 100,000 inhabitants $(17.4 \%)$ is notably over the average. Respondents in this segment have a medium-high consumption of fresh fruits (57.2\% 1 or twice a day). In relation to purchasing criteria, as said before, they stand out mainly for the importance they give to the price, although they are also above the total average in all the criteria. This is the segment with the highest number of family members, an aspect that could influence the care taken with food expenses. As for the consumption criteria, the extreme importance they give to the healthy properties of fruit and flavour stands out, a feature related with the preference for natural products and concern for health.

\section{Segment 4}

Unconcerned (UNC). This segment has the highest proportion of individuals aged under 35 and the lowest between 55 and 65 . In terms of consumer frequency, we can see that the range of 1 or 2 times a day (53.7\%) predominates, practically equal to the average for the population, but the frequency of three times a day or more $(32.7 \%)$ is shown to be significantly below average. These respondents consume less fresh fruit than the rest of the segments. As for the purchasing and consumption criteria, it particularly stands out in scores above the average for the middle scale answers in all the criteria. Therefore, its percentages are similar or below the total average for the extreme answers "Completely unimportant" and "Completely important". This result is consistent with their carefree nature, as it does not stand out especially in preferring any of the criteria studied. In summary, the data show a certain degree of indifference towards the consumption of fresh fruit, thus adapting to the name given.

The studies by Bernués et al. (2012), Bredahl and Grunert (1997), Buitrago-Vera et al. (2016) and Escriba-Perez et al. (2017) provide empirical support for the segments found in this study. In the most recent studies, Buitrago-Vera et al (2016) and Escriba-Perez et al (2017) obtained four similar FRL segments in Spain: the first, called "Unconcerned/Uninvolved", is very similar to what in this study are "UC" and "TI"; "Cooks" matches to "COOKNAT"; and finally, "Rational purchaser with little interest in cooking" plus "Out-of-home consumers and convenience shoppers" are here grouped into the "LICNE" segment. These similarities confirm the power of the FRL model to determine and characterise consumer segments and also confirm the FRL model's validity in a Western country, as stated by Grunert (2019).

\section{Limitations}

However, the limitations of this study should be noted for future studies. First, the size of the sample should be increased to achieve a better description of the smaller segments. Second, as the instrument is from 1997, some parts of it appear no longer up-to-date. For example, aspects of social responsibility and especially sustainability are not dealt with in the instrument (Grunert, 2019), and could be added in future revised versions. Third, as stated by Grunert (2019), "the FRL instrument still appears as a promising tool for segmentation when the aim is to segment consumers not only with regard to their reaction to products but in terms of how they react to food-related marketing efforts in general". Fourth, the complexity of the instrument, covering 23 dimensions in five domains, has been a barrier to its application, and a revised version of the instrument could adopt a modular approach (Grunert, 2019). 


\section{CONCLUSIONS AND RECOMMENDATIONS}

This paper analyses the data collected from a survey of 500 individuals, representative of the Spanish population in July 2017. A revised and previously tested version of the FRL instrument was used to explain the food attitudes of the Spanish population and their fresh fruit consumption habits and buying criteria.

This study shows that fresh fruit is consumed in Spain once or twice a day by $52.4 \%$ of the population and another $39.2 \%$ consumes it at a frequency of 3 times a day or more. Thus, we can state that approximately $90 \%$ of the population consumes fruit daily. These data are consistent with those from the Spanish national statistics. Nevertheless, the daily fruit consumption frequency is still below the standards recommended by the dietary pattern of the Mediterranean diet.

The 4 FRL segments identified are: "Total indifference (TI)", "Little time to cook, concerned about nutrition and extra-domestic consumption (LICNE)", "Cooks and preference for natural products (COOKNAT)" and "Unconcerned (UNC)". These segments have been sized and described and they show significant differences in fresh fruit purchasing and consumption criteria. Additionally, this study's findings are quite consistent with previous research using the FRL instrument in Spain.

Companies marketing and distributing fresh fruit are recommended to consider the main descriptive characteristics of each of the segments. The results of this study provide interesting insights for fresh fruit suppliers to Spain to develop different marketing mix strategies for each segment. These results may also be valuable for health practitioners and public health authorities, for targeted fruit and vegetables advertising. They could evolve from traditional advertisement campaigns (based on the product characteristics, influencers and famous athletes) to consumer-targeted initiatives using these FRL segments.

Finally, according to the results and limitations cited above, future research in FRL segmentation should follow a modular approach, using a revised and reduced version of the original FRL instrument, and adding items related to sustainability, food waste, heathy diet and social responsibility. These future studies should also empirically validate the FRL segmentations by linking measures of the segmentation base to some measures of reactions to marketing parameters, as suggested by Grunert (2019). 


\section{BIBLIOGRAPHY}

- $\quad$ Arroyo, P., Leire, U., Bergera, M., Rodríguez, P., Teresa, A., Gaspar, V., Moreno, E.R., et al. (2018), Frutas y Hortalizas: Nutrición y Salud En La España Del S. XXI. Avaliable at: https://www.fen.org.es/storage/app/media/imgPublicaciones/INFORME FRUTAS Y H ORTALIZAS FEN 2018-v1.pdf (accessed 12 June 2019)

- Bernués, A., Ripoll, G. and Panea, B. (2012), "Consumer segmentation based on convenience orientation and attitudes towards quality attributes of lamb meat", Food Quality and Preference, Vol. 26 No. 2, pp. 211-220.

- Bredahl, L. and Grunert, K.G. (1997). "Identificación de los estilos de vida alimenticios en España", Investigación agraria, Economía, Vol. 12 No. 1-3, pp. 247-264.

- Buckley, M., Cowan, C., McCarthy, M. and O'Sullivan, C. (2005), 'The Convenience Consumer and Food-Related Lifestyles in Great Britain', Journal of Food Products Marketing, Taylor \& Francis Group , Vol. 11 No. 3, pp. 3-25

- Buitrago-Vera, J., Escribá-Pérez, C., Baviera-Puig, A. y Montero-Vicente, L. (2016), "Consumer segmentation based on food-related lifestyles and analysis of rabbit meat consumption", World Rabbit Science, Universitat Politècnica de València, Vol. 24 No. 3, pp. 169-182.

- Cooremans, K., Geuens, M. and Pandelaere, M. (2017), "Cross-national investigation of the drivers of obesity: Re-assessment of past findings and avenues for the future", Appetite, Academic Press, Vol. 114, pp. 360-367.

- Díaz, C. (2014), "Hábitos alimentarios de los españoles. Cambios en las maneras de vivir, comprar y comer", Distribución y Consumo, Vol. 35, No. 5, pp. 20-29.

- Dimech, M., Caputo, V. and Canavari, M. (2011), "Attitudes of Maltese Consumers Towards Quality in Fruit and Vegetables in Relation to Their Food-Related Lifestyles", International Food and Agribusiness Management Review, Vol. 14 No. 4, pp. 21-35.

- Escriba-Perez, C., Baviera-Puig, A., Buitrago-Vera, J. and Montero-Vicente, L. (2017), "Consumer profile analysis for different types of meat in Spain", Meat Science, Elsevier, Vol. 129, pp. 120-126.

- EUROSTAT (2016), "Consumption of fruit and vegetables in the EU", EUROSTAT News release 197/2016, pp. 1-4, available at: http://ec.europa.eu/eurostat/documents/2995521/7694616/3-14102016-BPEN.pdf/1234ac94-27fd-4640-b9be-427a42d54881 (accessed 21/2/2018).

- Fraj Andrés, E., Martínez Salinas, E. and Grande Esteban, I. (2004), “Un estudio exploratorio sobre las variables psicográficas que influyen en el comportamiento del consumidor ecológico", Revista de Economía y Empresa, Vol. 21 No. 50, pp. 61-88.

- France, S.L. and Ghose, S. (2019), "Marketing analytics: Methods, practice, implementation, and links to other fields", Expert Systems with Applications, Pergamon, Vol. 119, pp. 456-475.

- Grunert, K.G., Bruns $\varnothing$, K. and Bisp, S. (1993), “Food-related life style: Development of a cross-culturally valid instrument for market surveillance", MAPP Working Paper No. 12, Aarhus University, Aarhus, October, available at: https://pure.au.dk/ws/files/88/wp12.pdf (accessed 20 February 2018).

- Grunert, K., Perrea, T., Zhou, Y., Huang, G., Sørensen, B. and Krystallis, A. (2011), 'Is food-related lifestyle (FRL) able to reveal food consumption patterns in non-Western cultural environments? Its adaptation and application in urban China', Appetite, Vol. 56 No. 2, pp. 357-367.

- Grunert, K.G. (2019), 'International segmentation in the food domain: Issues and approaches', Food Research International, Elsevier, Vol. 115, pp. 311-318. 
- Hair, J.F., Anderson, R.E., Tatham, R.L. and Black, W.C. (2008), Análisis Multivariante, Prentice Hall Iberia, Madrid.

- Kavak, B. and Gumusluoglu, L. (2007), "Segmenting food markets: The role of ethnocentrism and lifestyle in understanding purchasing intentions", International Journal of Market Research, Vol. 49, No. 1, pp. 71-94.

- Kotler, P., Kevin, K.L., Fabio, A. and Michelle, C. (2014), Marketing Management 14/E, Pearson Italia, Milan.

- Law, J. (2016), A dictionary of business and management, Oxford University Press, Oxford.

- Limeira, T. M. V. (2008), Comportamiento del consumidor brasilero, Saraiva, São Paulo.

- Montero-Vicente, L. (2015), La cadena de valor del sector cunícola en España. Segmentación del consumo en base al Food-Related Lifestyle (FRL), Universitat Politècnica de València, Valencia (Spain), available at: https://riunet.upv.es/handle/10251/58775 (accessed 9 August 2017].

- Morales, P. (2008), Estadística aplicada a las ciencias sociales, Universidad Pontificia Comillas, Madrid.

- Nie, C. and Zepeda, L. (2011), 'Lifestyle segmentation of US food shoppers to examine organic and local food consumption', Appetite, Vol. 57 No. 1, pp. 28-37.

- OECD. (2017), Health at a Glance 2017: OECD Indicators, OECD Publishing, Paris, France, available at: https://doi.org/10.1787/health glance-2017-en (accessed 13 June 2019).

- Pasamón, F. (2010), "La redefinición de la industria de alimentación y su distribución ante el nuevo consumidor", Alimentación en España, Producción, Industria, Distribución y Consumo 2010, pp 16-26, available at: http://www.mercasaediciones.es/alimentacion 2010/pdfs/pag 016-026 Pasamon.pdf, Mercasa, Madrid (accessed 2 August 2017).

- Pérez-Cueto, F.J.A., Verbeke, W., de Barcellos, M.D., Kehagia, O., Chryssochoidis, G., Scholderer, J. and Grunert, K.G. (2010), "Food-related lifestyles and their association to obesity in five European countries", Appetite, Vol. 54, No. 1, pp. 156-162.

- Pérez-López, C. (2004), Técnicas de análisis multivariante de datos. Aplicaciones con SPSS, Universidad Complutense de Madrid, Madrid.

- Resa, S. (2007), "Los platos preparados viven su momento de oro", Distribución y consumo, No. 94, pp. 71-75, available at:

https://www.mercasa.es/media/publicaciones/70/1288281172 DYC 2007947175. pdf (accessed 2 August 2017).

- Ryan, I., Cowan, C., McCarthy, M. and O'sullivan, C. (2004), 'Food-Related Lifestyle Segments in Ireland with a Convenience Orientation', Journal of International Food \& Agribusiness Marketing, Vol. 14 No. 4, pp. 29-47.

- Sánchez, M., Sanjuán, A., Gil Roig, J., Gracia, A. and Soler, F. (2002), “Organic produce: a study of consumer and specialist distributor preferences.", Economía Agraria y Recursos Naturales - Agricultural and Resource Economics, Vol. 2 No. 2, pp 93-114, available at : https://polipapers.upv.es/index.php/EARN/article/view/earn.2002.02.05 (accessed 2 August 2019).

- Scholderer, J., Brunsø, K., Bredahl, L. and Grunert, K. G. (2004), "Cross-cultural validity of the food-related lifestyles instrument (FRL) within Western Europe", Appetite, Vol. 42, No. 2, pp. 197-211.

- SPSS (2011) IBM SPSS statistics for Windows, version 20.0, IBM Corp, New York.

- Uriel, E. and Aldás, J. (2005). Análisis multivariante aplicado: aplicaciones al marketing, investigación de mercados, economía, dirección de empresas y turismo, ThomsonParaninfo, Madrid. 
- Van Huy, L.; Chi, M.T.T.; Lobo, A.; Nguyen, N.; Long, P.H. (2010), "Effective Segmentation of Organic Food Consumers in Vietnam Using Food-Related Lifestyles", Sustainability, Vol. 11 No. 5, pp.1237-1253

- Verain, M.C.D., Bartels, J., Dagevos, H., Sijtsema, S.J., Onwezen, M.C. and Antonides, G. (2012), 'Segments of sustainable food consumers: a literature review', International Journal of Consumer Studies, Vol. 36 No. 2, pp. 123-132.

- WHO (2003), Promoting fruit and vegetable consumption around the world, available at: https://www.who.int/dietphysicalactivity/fruit/en/ (accessed 29 August 2017].

- Wycherley, A., McCarthy, M. and Cowan, C. (2008), 'Speciality food orientation of food related lifestyle (FRL) segments in Great Britain', Food Quality and Preference, Vol. 19 No. 5, pp. 498-510.

\section{Further reading}

- Mallinson, L.J., Russell, J.M. and Barker, M.E. (2016), 'Attitudes and behaviour towards convenience food and food waste in the United Kingdom', Appetite, Vol. 103, pp. 1728. 
Table 1: Comparison between the sample and the Spanish population: age, people in the household and geographic area.

\begin{tabular}{|c|c|c|c|c|}
\hline Variables & $\begin{array}{l}\% \text { of the } \\
\text { Sample }\end{array}$ & $\begin{array}{c}\text { Sampling error } \\
\text { (95.5\% confidence } \\
\text { level) }\end{array}$ & $\begin{array}{c}\% \text { of Spanish } \\
\text { population } \\
\text { (INE) }\end{array}$ & $\begin{array}{c}\% \text { difference } \\
\text { in absolute } \\
\text { value }\end{array}$ \\
\hline
\end{tabular}

(A) (B) $\quad(\mathrm{A})-(\mathrm{B})$

\begin{tabular}{lllll}
\hline AGE & & & & \\
$25-34$ years old & 14.0 & 3.1 & 17.6 & 3.6 \\
$35-44$ years old & 23.8 & 3.8 & 24.8 & 1.0 \\
$45-54$ years old & 25.6 & 3.9 & 23.8 & 1.8 \\
$55-64$ years old & 19.8 & 3.6 & 19.1 & 0.7 \\
$65-74$ years old & 16.8 & 3.3 & 14.6 & 2.2
\end{tabular}

\section{PEOPLE IN THE HOUSEHOLD}

$\begin{array}{lrrrr}\text { Respondent only } & 8.2 & 2.5 & 10.2 & 2.0 \\ 2 & 25.2 & 3.9 & 24.4 & 0.8 \\ 3 & 23.4 & 3.8 & 25.1 & 1.7 \\ 4 & 29.2 & 4.1 & 28.2 & 1.0 \\ 5 & 7.0 & 2.3 & 9.1 & 2.1 \\ \text { More than 5 } & 4.0 & 1.8 & 3.0 & 1.0\end{array}$

Don't know/No answer $\quad 3.0$

NIELSEN GEOGRAPHIC AREA

\begin{tabular}{|c|c|c|c|c|}
\hline North-East & 14.2 & 3.1 & 14.1 & 0.1 \\
\hline East & 14.4 & 3.1 & 14.6 & 0.2 \\
\hline South & 24.2 & 3.8 & 24.4 & 0.2 \\
\hline Centre & 11.4 & 2.8 & 9.9 & 1.5 \\
\hline North-West & 9.2 & 2.6 & 9.1 & 0.1 \\
\hline North-Centre & 9.2 & 2.6 & 9.1 & 0.1 \\
\hline Madrid metropolitan area & 10.4 & 2.7 & 11.8 & 1.4 \\
\hline Barcelona metropolitan area & 7.0 & 2.3 & 7.0 & 0.0 \\
\hline
\end{tabular}

Source: Prepared by the authors based on the results of the survey and data for 2017 from National Statistics Institute (INE of Spain: www.ine.es). 
Table 2: Descriptive statistics for the items measuring food-related lifestyle.

I like to read the label of the food I buy to understand what's in it

I like shopping for food for my household

I'm on the lookout for changes in the price of food items that I buy regularly

I prefer to buy natural products such as products without preservatives

I always try to get the best quality at the lowest price when buying food

I like to try new foods

I believe it is more important to choose food items for their nutritional value than for their taste

I prefer fresh products to tinned or frozen products

I don't like to spend a lot of time cooking

I like to cook and experiment with new recipes

At home. we regularly use ready-to-eat food items such as salads
Likert scale

Strongly disagree $\quad 12.2$

Disagree

8.6

Neither agree nor disagree

Agree

Strongly agree

8.0

30.4

40.8

Strongly disagree $\quad 7.2$

Disagree $\quad 6.6$

Neither agree nor disagree $\quad 17.8$

Agree $\quad 34.8$

Strongly agree $\quad 33.6$

Strongly disagree $\quad 10.8$

Disagree $\quad 13.2$

Neither agree nor disagree $\quad 9.6$

Agree $\quad 27.4$

Strongly agree $\quad 39.0$

Strongly disagree $\quad 2.2$

Disagree $\quad 1.8$

Neither agree nor disagree $\quad 6.8$

Agree $\quad 29.8$

Strongly agree $\quad 59.4$

Strongly disagree $\quad 2.2$

Disagree $\quad 3.8$

Neither agree nor disagree $\quad 5.2$

Agree $\quad 27.0$

Strongly agree $\quad 61.8$

Strongly disagree $\quad 12.6$

Disagree $\quad 10.0$

Neither agree nor disagree $\quad 15.0$

Agree $\quad 26.8$

Strongly agree $\quad 35.6$

Strongly disagree $\quad 9.2$

Disagree $\quad 9.6$

Neither agree nor disagree $\quad 23.0$

Agree $\quad 25.8$

Strongly agree $\quad 32.4$

Strongly disagree $\quad 1.8$

Disagree $\quad .4$

Neither agree nor disagree $\quad 7.0$

Agree $\quad 29.2$

Strongly agree $\quad 61.6$

Strongly disagree $\quad 24.8$

Disagree $\quad 14.2$

Neither agree nor disagree $\quad 19.2$

Agree $\quad 20.0$

Strongly agree $\quad 21.8$

Strongly disagree $\quad 14.4$

Disagree $\quad 13.2$

Neither agree nor disagree $\quad 13.2$

Agree $\quad 25.6$

Strongly agree $\quad 33.6$

Strongly disagree $\quad 35.8$

Disagree $\quad 18.8$

Neither agree nor disagree $\quad 13.2$ 


\begin{tabular}{|c|c|c|}
\hline & Agree & 19.6 \\
\hline & Strongly agree & 12.6 \\
\hline My family is involved in preparing meals & Strongly disagree & 22.4 \\
\hline & Disagree & 13.6 \\
\hline & Neither agree nor disagree & 13.0 \\
\hline & Agree & 30.2 \\
\hline & Strongly agree & 20.8 \\
\hline I often decide what to cook at the last minute & Strongly disagree & 27.6 \\
\hline & Disagree & 14.4 \\
\hline & Neither agree nor disagree & 18.0 \\
\hline & Agree & 21.8 \\
\hline & Strongly agree & 18.2 \\
\hline I like going to restaurants with friends and family & Strongly disagree & 7.2 \\
\hline & Disagree & 9.6 \\
\hline & Neither agree nor disagree & 12.6 \\
\hline & Agree & 24.6 \\
\hline & Strongly agree & 46.0 \\
\hline I find cooking gratifying & Strongly disagree & 11.0 \\
\hline & Disagree & 8.6 \\
\hline & Neither agree nor disagree & 15.6 \\
\hline & Agree & 24.6 \\
\hline & Strongly agree & 40.2 \\
\hline I feel that eating with friends and family is an & Strongly disagree & 3.6 \\
\hline important part of my social life & Disagree & 3.6 \\
\hline & Neither agree nor disagree & 7.8 \\
\hline & Agree & 20.4 \\
\hline & Strongly agree & 64.6 \\
\hline
\end{tabular}


British Food Journal

Table 3. Factors extracted by Principal Components Analysis: initial and rotated matrix.

\begin{tabular}{|c|c|c|c|c|c|c|c|c|c|}
\hline \multirow[t]{2}{*}{ Factor } & \multicolumn{3}{|c|}{ Initial eigenvalues } & \multicolumn{3}{|c|}{$\begin{array}{l}\text { Sums of saturations to the } \\
\text { square of the extraction }\end{array}$} & \multicolumn{3}{|c|}{$\begin{array}{c}\text { Sum of saturations to the } \\
\text { square of the rotation }\end{array}$} \\
\hline & Total & $\begin{array}{c}\text { Variance } \\
\% \\
\end{array}$ & $\begin{array}{c}\text { Accumulated } \\
\%\end{array}$ & Total & $\begin{array}{c}\text { Variance } \\
\% \\
\end{array}$ & $\begin{array}{c}\text { Accumulated } \\
\%\end{array}$ & Total & $\begin{array}{c}\text { Variance } \\
\% \\
\end{array}$ & $\begin{array}{c}\text { Accumulated } \\
\%\end{array}$ \\
\hline 1 & 3.043 & 20.287 & 20.287 & 3.043 & 20.287 & 20.287 & 1.959 & 13.062 & 13.062 \\
\hline 2 & 1.435 & 9.569 & 29.856 & 1.435 & 9.569 & 29.856 & 1.839 & 12.262 & 25.323 \\
\hline 3 & 1.326 & 8.837 & 38.694 & 1.326 & 8.837 & 38.694 & 1.509 & 10.059 & 35.382 \\
\hline 4 & 1.216 & 8.109 & 46.803 & 1.216 & 8.109 & 46.803 & 1.400 & 9.331 & 44.714 \\
\hline 5 & 1.058 & 7.052 & 53.855 & 1.058 & 7.052 & 53.855 & 1.371 & 9.141 & 53.855 \\
\hline 6 & .960 & 6.401 & 60.255 & & & & & & \\
\hline 7 & .924 & 6.161 & 66.416 & & & & & & \\
\hline 8 & .844 & 5.629 & 72.045 & & & & & & \\
\hline 9 & .774 & 5.162 & 77.207 & & & & & & \\
\hline 10 & .731 & 4.873 & 82.080 & & & & & & \\
\hline 11 & .675 & 4.497 & 86.577 & & & & & & \\
\hline 12 & .608 & 4.051 & 90.628 & & & & & & \\
\hline 13 & .488 & 3.253 & 93.881 & & & & & & \\
\hline 14 & .467 & 3.110 & 96.991 & & & & & & \\
\hline 15 & .451 & 3.009 & 100.000 & & & & & & \\
\hline
\end{tabular}


Table 4. Factors loadings of the variables after applying varimax rotation ${ }^{1}$

\begin{tabular}{|c|c|c|c|c|c|}
\hline \multicolumn{6}{|c|}{ Rotated components matrix } \\
\hline & \multicolumn{5}{|c|}{ Factors from PCA } \\
\hline & $\begin{array}{l}\text { F1: } \\
\text { Overall } \\
\text { liking } \\
\text { for } \\
\text { cooking }\end{array}$ & $\begin{array}{l}\text { F2: } \\
\text { Interest } \\
\text { in natural } \\
\text { products }\end{array}$ & $\begin{array}{l}\text { F3: } \\
\text { Quality/price } \\
\text { ratio. } \\
\text { involved and } \\
\text { convenience }\end{array}$ & $\begin{array}{l}\text { F4: Extra- } \\
\text { domestic and } \\
\text { social } \\
\text { consumption }\end{array}$ & $\begin{array}{c}\text { F5: } \\
\text { Not a } \\
\text { cook but } \\
\text { interested } \\
\text { in nutrition } \\
\text { and } \\
\text { innovation }\end{array}$ \\
\hline I find cooking gratifying & .810 & .046 & .099 & .007 & -.100 \\
\hline $\begin{array}{l}\text { I like to cook and experiment with new } \\
\text { recipes }\end{array}$ & .776 & .009 & .035 & .147 & .050 \\
\hline I like shopping for food for my household & .394 & .164 & .037 & -.054 & .326 \\
\hline $\begin{array}{l}\text { I prefer to buy natural products such as } \\
\text { products without preservatives }\end{array}$ & .050 & .803 & .104 & .016 & .083 \\
\hline $\begin{array}{l}\text { I prefer fresh products to tinned or frozen } \\
\text { products }\end{array}$ & .161 & .684 & -.040 & .214 & .126 \\
\hline $\begin{array}{l}\text { I'm on the lookout for changes in the } \\
\text { price of food items that I buy regularly }\end{array}$ & .127 & .206 & .640 & -.152 & .120 \\
\hline My family is involved in preparing meal & .176 & -.078 & .583 & .209 & -.083 \\
\hline $\begin{array}{l}\text { I always try to get the best quality at the } \\
\text { lowest price when buying food }\end{array}$ & -.162 & .516 & .529 & .062 & -.026 \\
\hline $\begin{array}{l}\text { At home, we regularly use ready-to-eat } \\
\text { food items such as salads }\end{array}$ & -.113 & -.390 & .469 & .172 & .266 \\
\hline $\begin{array}{l}\text { I like going to restaurants with friends } \\
\text { and family }\end{array}$ & -.060 & .032 & .013 & .838 & -.006 \\
\hline $\begin{array}{l}\text { I feel that eating with friends and family } \\
\text { is an important part of my social life }\end{array}$ & .381 & .236 & .124 & .591 & .067 \\
\hline I don't like to spend a lot of time cooking & -.242 & -.105 & -.152 & .183 & $.719^{\star}$ \\
\hline $\begin{array}{l}\text { I believe it is more important to choose } \\
\text { food items for their nutritional value than } \\
\text { for their taste }\end{array}$ & .185 & .253 & .202 & -.221 & .590 \\
\hline I like to try new foods & .279 & .091 & .214 & .298 & .389 \\
\hline $\begin{array}{l}\text { I like to read the label of the food I buy to } \\
\text { understand what's in it }\end{array}$ & .336 & .303 & .331 & -.078 & .342 \\
\hline
\end{tabular}

${ }^{1}$ Bold values indicate higher factor loadings (higher correlation between variables and factors) 
Table 5. Factor loadings of the FRL segments ${ }^{1}$

\begin{tabular}{|l|c|c|c|c|}
\hline \multicolumn{1}{|c|}{ Factor } & TI & LICNE & COOKNAT & UNC \\
\hline Overall interest in cooking & -1.77 & -0.58 & 0.41 & 0.20 \\
\hline Interest in natural products & -0.66 & 0.46 & 0.47 & -0.96 \\
\hline $\begin{array}{l}\text { Quality/price ratio. involved } \\
\text { and convenience }\end{array}$ & -0.11 & -0.40 & 0.28 & 0.00 \\
\hline $\begin{array}{l}\text { Extra-domestic and social } \\
\text { consumption }\end{array}$ & -2.17 & 0.29 & -0.08 & 0.15 \\
\hline $\begin{array}{l}\text { Not a cook. but interested in } \\
\text { nutrition and innovation }\end{array}$ & -1.03 & 0.73 & -0.49 & 0.16 \\
\hline Total & 20 & 132 & 201 & 147 \\
\hline$\%$ & $4.0 \%$ & $26.4 \%$ & $40.2 \%$ & $29.4 \%$ \\
\hline
\end{tabular}

${ }^{1}$ Bold values indicates factor loading values greater than 0.3 (considered significant). 
Table 6: Sociodemographic characteristics of the FRL segments (\%)

\begin{tabular}{|c|c|c|c|c|c|}
\hline Variables & TI & LICNE & COOKNAT & UNC & Total \\
\hline \multicolumn{6}{|l|}{$\mathrm{AGE}^{*}$} \\
\hline 25-34 years old & 10.0 & 6.8 & 13.9 & 21.1 & 14.0 \\
\hline $35-44$ years old & 5.0 & 24.2 & 23.9 & 25.9 & 23.8 \\
\hline 45-54 years old & 20.0 & 30.3 & 25.9 & 21.8 & 25.6 \\
\hline 55-64 years old & 20.0 & 22.0 & 21.9 & 15.0 & 19.8 \\
\hline $65-74$ years old & 45.0 & 16.7 & 14.4 & 16.3 & 16.8 \\
\hline \multicolumn{6}{|c|}{ PEOPLE IN THE HOUSEHOLD ** } \\
\hline Respondent only & 10.0 & 9.8 & 5.0 & 10.9 & 8.2 \\
\hline 2 & 40.0 & 31.1 & 22.4 & 21.8 & 25.2 \\
\hline 3 & 10.0 & 23.5 & 22.4 & 26.5 & 23.4 \\
\hline 4 & 25.0 & 24.2 & 34.8 & 26.5 & 29.2 \\
\hline 5 & 0.0 & 4.5 & 8.5 & 8.2 & 7.0 \\
\hline More than 5 & 0.0 & 4.5 & 4.0 & 4.1 & 4.0 \\
\hline Don't know/Don't answer & 15.0 & 2.3 & 3.0 & 2.0 & 3.0 \\
\hline \multicolumn{6}{|l|}{ RESIDENCE HABITAT ** } \\
\hline $\begin{array}{l}\text { Less than } 10.000 \\
\text { inhabitants. }\end{array}$ & 25.0 & 30.3 & 28.4 & 23.8 & 27.4 \\
\hline $\begin{array}{l}\text { From } 10.000 \text { to } 50.000 \\
\text { inhabitants. }\end{array}$ & 20.0 & 22.7 & 25.9 & 29.3 & 25.8 \\
\hline $\begin{array}{l}\text { From } 50.001 \text { to } 100.000 \\
\text { inhabitants. }\end{array}$ & 10.0 & 7.6 & 17.4 & 4.1 & 10.6 \\
\hline $\begin{array}{l}\text { From } 100.001 \text { to } 500.000 \\
\text { inhabitants. }\end{array}$ & 30.0 & 22.0 & 13.9 & 23.1 & 19.4 \\
\hline $\begin{array}{l}\text { More than } 500.000 \\
\text { inhabitants. }\end{array}$ & 15.0 & 17.4 & 14.4 & 19.7 & 16.8 \\
\hline
\end{tabular}

*Statistically significant at $99 \%$ confidence level.

$* *$ Statistically significant at $95 \%$ confidence level.

${ }^{1}$ The segment values that exceed the total average by more than 4 percentage points appear in bold. 
Table 7: Fresh fruit consumption frequency of the FRL segments $(\%)^{1}$

\begin{tabular}{|c|c|c|c|c|c|}
\hline Variables & TI & LICNE & COOKNAT & UNC & Total \\
\hline \multicolumn{6}{|c|}{ CONSUMPTION FREQUENCY * } \\
\hline 3 or more times a day & 40.0 & 51.5 & 35.8 & 32.7 & 39.2 \\
\hline 1 or 2 times a day & 55.0 & 43.2 & 57.2 & 53.7 & 52.4 \\
\hline $\begin{array}{l}\text { Between } 3 \text { and } 6 \text { times } \\
\text { a week }\end{array}$ & 0.0 & 3.0 & 4.5 & 8.8 & 5.2 \\
\hline 1 or 2 times a week & 0.0 & 1.5 & 1.5 & 3.4 & 2.0 \\
\hline Less frequently & 0.0 & 0.8 & 1.0 & 0.7 & 0.8 \\
\hline No consumption & 0.0 & 0.0 & 0.0 & 0.7 & 0.2 \\
\hline NS/NA & 5.0 & 0.0 & 0.0 & 0.0 & 0.2 \\
\hline
\end{tabular}

*Statistically significant at $99 \%$ confidence level.

${ }^{1}$ The segment values that exceed the total average by more than 4 percentage points appear in bold 
Table 8: Fresh fruit purchasing criteria of the FRL segments $(\%)^{1}$

\begin{tabular}{|c|c|c|c|c|c|}
\hline Variables & TI & LICNE & COOKNAT & UNC & Total \\
\hline \multicolumn{6}{|c|}{ GEOGRAPHICAL ORIGIN OF THE PRODUCT** } \\
\hline $\begin{array}{l}\text { Completely } \\
\text { unimportant }\end{array}$ & 30.0 & 14.4 & 13.4 & 19.7 & 16.2 \\
\hline Quite unimportant & 20.0 & 8.3 & 9.0 & 11.6 & 10.0 \\
\hline Somewhat important & 10.0 & 6.8 & 7.5 & 14.3 & 9.4 \\
\hline Quite important & 20.0 & 15.9 & 18.9 & 30.6 & 21.6 \\
\hline Extremely important & 20.0 & 54.5 & 51.2 & 23.8 & 42.8 \\
\hline \multicolumn{6}{|c|}{ ITEM APPEARANCE* } \\
\hline $\begin{array}{l}\text { Completely } \\
\text { unimportant }\end{array}$ & 15.0 & 2.3 & 4.0 & 0.7 & 3.0 \\
\hline Quite unimportant & 0.0 & 3.0 & 3.0 & 4.8 & 3.4 \\
\hline Somewhat important & 10.0 & 6.1 & 3.0 & 7.5 & 5.4 \\
\hline Quite important & 20.0 & 18.2 & 17.4 & 33.3 & 22.4 \\
\hline \multicolumn{6}{|l|}{ PRICE*** } \\
\hline $\begin{array}{l}\text { Completely } \\
\text { unimportant }\end{array}$ & 25.0 & 6.8 & 8.5 & 5.4 & 7.8 \\
\hline Quite unimportant & 5.0 & 6.8 & 6.5 & 6.1 & 6.4 \\
\hline Somewhat important & 15.0 & 19.7 & 13.9 & 22.4 & 18.0 \\
\hline Quite important & 10.0 & 19.7 & 15.4 & 23.8 & 18.8 \\
\hline Extremely important & 45.0 & 47.0 & 55.7 & 42.2 & 49.0 \\
\hline \multicolumn{6}{|c|}{ SHOPKEEPER RECOMMENDATION* } \\
\hline $\begin{array}{l}\text { Completely } \\
\text { unimportant }\end{array}$ & 40.0 & 12.1 & 11.4 & 19.0 & 15.0 \\
\hline Quite unimportant & 15.0 & 7.6 & 11.4 & 12.9 & 11.0 \\
\hline Somewhat important & 20.0 & 18.9 & 21.4 & 21.8 & 20.8 \\
\hline Quite important & 20.0 & 25.8 & 21.9 & 28.6 & 24.8 \\
\hline Extremely important & 5.0 & 35.6 & 33.8 & 17.7 & 28.4 \\
\hline \multicolumn{6}{|c|}{ PRODUCT INFORMATION* } \\
\hline $\begin{array}{l}\text { Completely } \\
\text { unimportant }\end{array}$ & 40.0 & 22.7 & 19.9 & 23.1 & 22.4 \\
\hline Quite unimportant & 15.0 & 12.9 & 9.5 & 17.7 & 13.0 \\
\hline Somewhat important & 15.0 & 6.8 & 10.4 & 8.8 & 9.2 \\
\hline Quite important & 15.0 & 12.9 & 16.9 & 29.3 & 19.4 \\
\hline Extremely important & 15.0 & 44.7 & 43.3 & 21.1 & 36.0 \\
\hline \multicolumn{6}{|l|}{ PRODUCT BRAND* } \\
\hline $\begin{array}{l}\text { Completely } \\
\text { unimportant }\end{array}$ & 50.0 & 28.8 & 22.9 & 28.6 & 27.2 \\
\hline Quite unimportant & 15.0 & 13.6 & 16.4 & 25.2 & 18.2 \\
\hline Somewhat important & 20.0 & 11.4 & 14.4 & 12.9 & 13.4 \\
\hline Quite important & 5.0 & 16.7 & 14.4 & 22.4 & 17.0 \\
\hline Extremely important & 10.0 & 29.5 & 31.8 & 10.9 & 24.2 \\
\hline
\end{tabular}

*Statistically significant at $99 \%$ confidence level.

$* * *$ Statistically significant at $90 \%$ confidence level.

${ }^{1}$ The segment values that exceed the total average by more than 4 percentage points appear in bold 
Table 9: Fresh fruit consumption criteria of the FRL segments $(\%)^{1}$

\begin{tabular}{|c|c|c|c|c|c|}
\hline Variables & $\mathrm{TI}$ & LICNE & COOKNAT & UNC & Total \\
\hline \multicolumn{6}{|c|}{ HEALTHY PROPERTIES* } \\
\hline $\begin{array}{l}\text { Completely } \\
\text { unimportant }\end{array}$ & 35.0 & 9.1 & 6.5 & 8.8 & 9.0 \\
\hline Quite unimportant & 10.0 & 6.1 & 3.0 & 8.2 & 5.6 \\
\hline Somewhat important & 10.0 & 3.8 & 6.5 & 9.5 & 6.8 \\
\hline Quite important & 15.0 & 26.5 & 22.4 & 39.5 & 28.2 \\
\hline Extremely important & 30.0 & 54.5 & 61.7 & 34.0 & 50.4 \\
\hline \multicolumn{6}{|l|}{ FLAVOUR $*$} \\
\hline $\begin{array}{l}\text { Completely } \\
\text { unimportant }\end{array}$ & 30.0 & 2.3 & 3.5 & 2.0 & 3.8 \\
\hline Quite unimportant & 0.0 & 3.0 & 2.0 & 2.7 & 2.4 \\
\hline Somewhat important & 20.0 & 4.5 & 4.0 & 4.8 & 5.0 \\
\hline Quite important & 30.0 & 21.2 & 16.4 & 40.1 & 25.2 \\
\hline Extremely important & 20.0 & 68.9 & 74.1 & 50.3 & 63.6 \\
\hline \multicolumn{6}{|l|}{ NON-FATTENING* } \\
\hline $\begin{array}{l}\text { Completely } \\
\text { unimportant }\end{array}$ & 50.0 & 21.2 & 21.4 & 23.1 & 23.0 \\
\hline Quite unimportant & 20.0 & 12.1 & 18.9 & 24.5 & 18.8 \\
\hline Somewhat important & 20.0 & 23.5 & 20.4 & 13.6 & 19.2 \\
\hline Quite important & 0.0 & 20.5 & 15.4 & 27.2 & 19.6 \\
\hline Extremely important & 10.0 & 22.7 & 23.9 & 11.6 & 19.4 \\
\hline
\end{tabular}

*Statistically significant at $99 \%$ confidence level.

The segment values that exceed the total average by more than 4 percentage points appear in bold 